\title{
34 \\ Trouble in the Heartland: \\ GIS and Its Critics in the 1990s
}

\author{
Nadine Schuurman \\ 2000. Progress in Human Geography 24, 4, 569-90. ${ }^{1}$
}

If we could bring ourselves to accept the fact that no theory about the nature of Man or Society or Rationality, or anything else, is going to synthesize Nietzsche with Marx or Heidegger with Habermas, we could begin to think of the relation between writers on autonomy and writers on justice as being like the relation between two kinds of tools - as little in need of synthesis as are paintbrushes and crowbars ... Both are right, but there is no way to make both speak a single language (Rorty, 1989, xiv).

It's funny how old (and tiresome?) debates in geography never die, they just find new battlefields (Walton, 1995, 6).

In geography, the most guarded territory is not the earth but disciplinary methodologies and, by implication, the lenses through which the earth is viewed. The introduction of GIS has done nothing to mitigate these divisions. When human and cultural geographers first turned their attention to GIS, they sparked a debate, and subsequent discussions about the merits of GIS have permeated the culture of geography. Certainly, the controversies escaped the notice of very few people in the discipline. As a result, they have begun to stand in for broader disciplinary debates over methods and epistemology. Given that different people picked up the debate at various times and others heard about it second or third hand, it is worth reviewing them precisely because debates about GIS have had effects on the discipline of

\footnotetext{
${ }^{1}$ Reprinted with permission from SAGE Publications and Nadine Schuurman.
} 
geography as well as the way we do GIS. The history of these exchanges informs and shapes the culture of our discipline.

I begin by delineating the battle lines of a broader arena - the so-called science wars. Sociological studies of science and technology predate discord about GIS. Tensions between scientists and critics from sociology are an expression of differing approaches to the study of the physical and social world. Though positions along similar lines are found in debates in geography, discussions over GIS are unique to the discipline. I have organized these critiques and their responses from GIS practitioners into three waves or periods, each distinguished by shifts in strategies and motivation on the part of critics. The first wave, from 1990 to 1994, was distinguished by the animosity of debate. Despite overt disciplinary hostility, a number of GIS researchers did engage in these discussions and a dialog of sorts resulted. By the middle of the decade, however, the ranks of critics had increased while defenses from GIS had tapered off. A few GIS scholars welcomed the intervention and felt the critiques expressed critical shortcomings of GIS (Poiker, pers. interview, 1997; Harvey and Chrisman, 1998). Others were disturbed by the clear lack of understanding of GIS exhibited by critics (Openshaw, 1991; Clarke, pers. interview, 1998; Marble, pers. interview, 1998). At the same time, a number of critics and GIS researchers had begun to work together on NCGIA Initiative 19. Critics were drawn into the upper echelons of GIS research, and the present era of increased co-operation between critics and the GIS community was initiated. In the final section, I discuss the possibilities and realities of effective intervention between sectors of the discipline.

\section{Contextualizing Discord in Geography}

Debates in geography are neither restricted to nor indigenous to the discipline. A brief detour to outline salient points of the recent and controversial science wars is warranted on two accounts. The first is that there are parallels between discord in geography and the science wars, especially with regard to divisions between scientists and social scientists. More importantly, there are notable differences between the two arenas and, unless these discrepancies are identified, a tendency not to differentiate prevails. This does a disservice to both sides in the debates over GIS. For the critics, it trivializes their criticism by assuming that they are repeating axioms from science and technology studies (STS). It also fails to recognize that many STS researchers focus on fields other than their own. In STS, sociologists study and critique physics or biology. In geography, however, critics have turned their attention to their own field, an area in which they have considerably more stake (Curry, pers. comm.). Thus, homogenizing geography debates with the science wars undermines the considerable efforts made by the GIS community to accommodate criticism [...]. It also discounts the willingness of critics to work with GIS scholars (Pickles, 1999).

At the core of this complicated and contentious dispute, known as the science wars, is the epistemological privilege enjoyed by science and the degree to which 
science is culturally influenced. Even a rudimentary outline of the dissension would note that social scientists are increasingly critical of science "proper" (Gross, 1996; Haraway, 1991; Harding, 1991; Latour, 1993; Pickering, 1995; Rouse, 1996). Proponents of traditional science have defended themselves with the publication of books and articles intended to undermine the politics and motivation of its critics (Gross and Levitt, 1994; Gross et al., 1996; Koertge, 1998; Sokal, 1996a; 1996b). The science wars were made truly contentious by the 1996 publication of an article called "Transgressing the boundaries" by physicist Alan Sokal. Sokal putatively discussed parallels between twentieth century mathematics and physics and their relation to ongoing work in STS. His was a dense, meandering text which should not have evoked much comment nestled in the company of excellent companion pieces on the cultural construction of science. On the day of its publication in Social Text, however, Sokal published an exposition in Lingua Franca in which he claimed that his article was a hoax, a parody of attempts by social science to link science and culture. The New York Times considered this trick worthy of an editorial (Fish, 1996) and Sokal, himself, was eager to talk to the media. The science wars had gone public. In the aftermath, there have been many rounds of debate, often with little public evidence of a willingness to acknowledge the arguments of the opposing side.

The science wars are part of a broader negotiation over the value and meaning of science and technology and their relationship to the culture in which they are embedded. While these epistemological battles brewed, quiet tensions had been mounting in geography. Human geographers were not immune to the growing body of work on the interdigitization of science and culture. Articles discussing the merits of cultural studies of science made their way into geography (Barnes, 1993; Billinge et al., 1984; Demeritt, 1996). They were, in a sense, the continuation of a tradition of criticism focusing on positivism in geography. It was only a matter of time before GIS, at first glance a rapidly growing positivist technology, attracted the attention of human geographers.

Critics of GIS from human geography neither exclusively emphasized the social construction of GIS nor did they, for the most part, engage with the theoretical critiques emerging from STS. Staples of STS such as actor-network theory (Latour, $1987 ; 1988$ ) and the symmetry of true and false claims (Kitcher, 1998) were eschewed in favor of epistemological arguments and specific attention to the effects of GIS on objects of its scrutiny, as well as the direction of the discipline. Nor did critics of GIS engage in the questionable tactics used by Allan Sokal to suggest that the editors of Social Text were incompetent. Debates over GIS in geography were overt and apparently motivated by a genuine desire on both sides to steer the discipline in an appropriate and responsible direction, despite occasional outbreaks of hostility (Pickles, 1999). The history and content of those debates are as distinguished by their differences from the science wars as their similarities. The parallels are obvious. It is the nuances of the debate within geography that shape the remainder of this article. 


\section{Early Rumblings: The First Wave}

Early debates about GIS were conversations, despite their incarnation as published texts. Their treatment herein largely follows the chronology and forum of their publication, a necessary tactic as many of the initial debates, ensconced in commentary sections of journals, were, in fact, responses to previous challenges, spiraling conversations within the bounds of geography's journals. Because of their passion, these repartees of the early 1990s are central to discerning the stakes represented by GIS. With their glimmers of antagonism and disciplinary agendas, these early exchanges reveal a great deal about the motivations of both critics and defenders of the technology.

GIS developed within geography without ostensible friction until the 1990s, when a flurry of commentaries about the relative merits of GIS made its way into its journals. Early dissent was sparked by an editorial by Peter Taylor, entitled "GKS" or "geographic knowledge systems". Taylor's article expressed sentiments, on the part of human geographers, that had been growing over the previous few years. Taylor (1990, 211) linked GIS to Mackinder's "new" geography which fused so well with the "age of imperialism". GIS, he suggested, while well equipped to manage information, is inadequate in the realm of knowledge production, concerned with facts but incapable of meaningful analyses. Taylor $(1990,211)$ elaborated: " $\{h\}$ ence theories and abstractions are relegated and geography returns to describing the world." Taylor (1990, 212) concluded that a geography based on "facts" will become a "trivial pursuit' geography .... a return of the very worst sort of positivism, a most naive empiricism". Such a geography, he implied, will wither "after the initial technological flush".

Michael Goodchild, a prominent GIS researcher, responded to Taylor in the next issue of Political Geography Quarterly (1991). Rather than extol the virtues of GIS, Goodchild argued that while the technological structure of GIS is controlled by computer science, the development of GIS in geography has led to the realization that databases and processes can be inaccurate. He suggested that GIS has made its own limitations an integral part of its research for decades [...]. Furthermore, he argued that GIS is most useful precisely when it is "guided by people trained in the nature of geographical phenomena", (Goodchild, 1991, 336), that GIS is designed to be used in conjunction with knowledge rather than a substitute for it. GIS, without geography, Goodchild implied, is indeed a naive and dangerous empiricism. Against Taylor's assertion that GIS is the "positivists' revenge" (Taylor, 1990, 212), Goodchild [...] differentiated GIS from quantitative geography, pointing to the "fuzziness and generalization" involved in cartography. He did, nevertheless, ask if positivism does not have some uses in the social sciences. This possibility, according to Goodchild, does not make GIS a "mere tool" but rather a means of provoking "profound geographical thoughts" (Goodchild, 1991, 336).

Taylor's initial editorial brought into the open a recognition that GIS was changing the discipline, an assertion Goodchild defended. It was within the pages of 
Environment and Planning $A$ that debates about GIS in geography truly proliferated. Some articles exposed hostility between members of the GIS community and human geographers. Heated opinions and barbed comments marked Stan Openshaw's (1991) initial sally entitled "A view on the GIS crisis in geography, or, using GIS to put Humpty-Dumpty back together again". Openshaw began by hesitating about having the discussion at all, given its "potentially divisive" nature. He intimated that people in GIS have felt censured by other geographers and "their misinformed speculation about what GIS is and does, and how it either fits or does not fit comfortably within geography" (Openshaw, 1991, 621). His initial hesitation about the constructiveness of such debates quickly overcome, Openshaw stated that his contribution would not be relevant if "GISers and non GISers ... \{were $\}$ not in competition for resources or the high ground" (Openshaw, 1991, 621). Openshaw was impatient with GIS' nay-sayers and berated critics for their own qualitative methodologies that had dismissed any relationship to maps. A number of hostile statements on the inferiority of non GISers, clearly meant to solidify the position of GIS in this battle for disciplinary supremacy, were issued. The reputed ignorance of computer techniques on the part of human geographers was a case in point: "most of the technical cripples in geography seemed to have survived the increasing use of computer technology by essentially ignoring most computer-based developments ..." (Openshaw, 1991, 624). Not only did Openshaw presume that the disciplinary struggle over methodology was over (won by the GISers, presumably), but that geographers who resisted this lens were simply ignorant of computers. Nontechnical geographers were also accused of actively opposing disciplinary unity:

the counterrevolutionary strategy \{of non GISers\} appears to be based on building up a range of conception-theoretical arguments $\{$ sic $\}$ against it $\{$ GIS \}, express them in pseudophilosophical languages to provide a veneer of academic respectability, add a few misquotes from famous dead people who lived in a totally different world, and wait five years for the reaction to go critical (Openshaw, 1991, 622).

Referring to Taylor's criticisms that GIS is a retreat from information, Openshaw (1991, 621) queried: "without information, how can there be knowledge?" Unlike Taylor, Openshaw welcomed the opportunities that GIS allowed for geographers to participate in other disciplines. A geographer of the impending new order may well be able to:

analyze river networks on Mars on Monday, study cancer in Bristol on Tuesday, map the underclass of London on Wednesday, analyze groundwater flow in the Amazon basin on Thursday, and end the week 
by modeling retail shoppers in Los Angeles on Friday. What of it? Indeed this is only the beginning (Openshaw, 1991, 624). ${ }^{2}$

GIS was not only positioned to make inroads into (every) other discipline but to absorb "soft analysis problems" by implementing computer solutions from artificial intelligence (AI). Taylor's worst fears about geographic imperialism were born out on two fronts. Openshaw envisaged GIS as invading other disciplines while also incorporating human geographers.

While inflammatory, Openshaw's arguments reflected tensions within the discipline ${ }^{3}$. Despite their crudeness and will to power, his explication(s) were valuable as an overt representation of a budding antagonism between GISers and human geographers. Openshaw directly tackled issues hitherto evaded in the press (though perhaps elaborated during informal discussions). He suggested that critics of GIS were motivated not only by a quest for epistemological integrity but also by a desire to retain disciplinary authority. Openshaw also emphasized that technologies encompassed in GIS reflect a social shift that cannot be contained within geography. Data are increasingly digital; visual analysis is usurping text; and mapping has disseminated into other disciplines over which geographers exert little influence. In essence, digital mapping and its attendant principles have exceeded the boundaries of geography.

Responses to Openshaw in Environment and Planning $A$ again sublimated this disciplinary disquietude within carefully constructed and academically worded rationales for alignment with either the "GISers or non GISers." The first response to Openshaw's provocation, by Peter Taylor and Mark Overton, easily dissembled Openshaw's arguments on three main bases: 1) philosophical incongruence; 2) too much hype and belligerence; and 3) the social nature of geography and all disciplines. Their initial and well justified point was that Openshaw's proposal for a "philosophy free" geography is "a fundamental philosophical claim" (Taylor and Overton, 1991, 1087). Taylor and Overton's second criticism of Openshaw centered on his pugnacious rhetoric. Used to denigrate nontechnical human geographers and to establish their inferiority, it was alienating, unwarranted and counterproductive. Likewise, their call for attention to ways that the social is written into technology was well timed and apt. The measured arguments of Taylor and Overton, while effective, fell short of specifying what Openshaw did not shy from: that there are material stakes in their confrontation.

2 Openshaw clearly worked with a more robust and seamless GIS than the rest of us. As Stacy Warren (pers. comm.) volunteered, "I'd still be labeling Tuesday's cancer polygons on Friday."

${ }^{3}$ That Taylor and Openshaw worked in the same department at Newcastle may have had some bearing on the tone of their respective editorials. 
Taylor's was not the only reply to Openshaw in Environment and Planning A. Gordon L. Clark (1992), in a commentary entitled "GIS - what crisis?", berated both parties. He acknowledged that Openshaw was provoked by Taylor's initial critique of GIS which he implied was inspired by the (reputed) disdain of some "postmodernists" for "knowledge and reason" (Clark, 1992, 321). But rather than brand all alleged postmodernists as anti-GIS, Clark conducted an informal poll of his "postmodernist" friends only to find them uniformly enthusiastic about GIS technology. Their fears revolved around insufficient staffing in GIS rather than a disciplinary coup. His conclusion was that Openshaw had "exaggerated the hostility to GIS" $(1992,321)$ while correctly identifying an inexorable trend toward cybernetic systems. Clark's contribution to discussions of GIS lay, however, in identifying that GIS is not only a (sub)discipline but also an industry. Clark suggested the proliferation of commercial interests in GIS threatens the type of "blue-sky" research which universities conduct research which, despite its underlying reliance on representational realism, endeavors to model the world more precisely. Clark $(1992,322)$ concluded that "it is going to become crucial for universities to identify some comparative advantage in the GIS market not easily penetrated by commercial companies". From this perspective, squabbles within geography lose relevance.

They do, however, persist. Openshaw rallied with another contribution to the commentary section of Environment and Planning A in April of 1992. Despite his emblematic rhetoric, including a characterization of human geographers as "technical cripples" (Openshaw, 1992, 464), Openshaw identified a critical issue: some knowledge of GIS is essential to address its shortcomings. Openshaw (1992: 465) offered that "it is particularly important that those who comment on GIS should be properly informed and base their comments and criticism on some knowledge and experience of what GIS can and cannot do". In concluding, he further postulated "that after all this puff ... it will be discovered that we are in fact saying essentially the same or similar things in different ways, in different languages" (Openshaw, 1992, 465-66, emphasis added). Openshaw recognized that discourse divides the discipline. Much GIS literature does, in fact, deal explicitly with the technology's shortcomings but is delivered in its own language and journals.

\section{The Purported Poverty of Positivism and Other Failings}

Debates about the significance of GIS were not limited to Environment and Planning A. It was one of several theaters for disciplinary disagreements over GIS. Conducted in a less excited tone, subsequent academic challenges nevertheless confirmed that the place of GIS within the discipline of geography was being negotiated. Neil Smith outlined his concerns in Progress in Human Geography in 1992 with a contribution entitled "History and philosophy of geography: real wars, theory wars". His oeuvre in the GIS wars began with a critical account of the involvement of GIS in the Gulf war, linking the estimated 200000 Iraqi deaths to geographic technologies. "Thus," Smith $(1992,257)$ wrote, "did GIS and related technologies 
contribute to the killing fields of the Iraqi desert." Smith equated the scientization of cartography with a strident technocraticism and suggested that Openshaw's undiluted enthusiasm for the technology reflected a "delirious detachment" (Smith, 1992, 25859). Yet, he authoritatively quoted Taylor's (1991) characterization of GIS as "a return of the very worst sort of positivism, a most naïve empiricism" (Taylor, cited in Smith, 1992, 258). I cite this selective support of participants in the GIS skirmishes because it is indicative of a tendency, in this debate, to exonerate the excesses of those whose arguments the author champions while caricaturizing the arguments and delivery of antagonists. This is not a phenomenon limited to the world of geography. It is the stock and trade of larger debates on the science wars. Use of caricatures occurs precisely because they do such a good job of undermining (perceived) opposition.

This observation is not intended, in any way, to detract from Smith's critical and important call for attention to the uses of GIS in war. Smith's careful enumeration of the people employed in military development of GIS and its considerable underwriting by defense agencies (Smith, 1992, 258) marked the initiation of a more constructive conversation about GIS. His arguments pierced the balloon of disciplinary pride which had puffed up claims from both sides. The bottom line is that technology can wound and kill, and it is essential that geography examine its culpability. What Smith wrote did not attend to the more complex argument of whether or not GIS research, much of which is unrelated to military pursuits, can necessarily be linked to its implementation.

Attention to epistemology, initiated by Smith, was continued by Robert Lake, who examined GIS on the basis of ethics and ontology. His arguments were woven together by one thread: positivism. Lake defined positivism as encompassing "assumptions of objectivity, value-neutrality, and the ontological separation of subject and object" (Lake, 1993, 405). This seems plausible as a definition, but more open to debates is his subsequent assertion that 1) GIS is inherently positivist; 2) that its ethics are objectionable because they derive from positivist assumptions; and 3) that the "subject-object dualism underlying" GIS is a positivist legacy. By 1993, positivism had become a primary basis for critiques of GIS. For Lake, positivism was the [indispensable] criticism [...] against GIS. Furthermore, he implied that reconciliation between the two factions of geography is only possible to the extent that GIS is willing to incorporate the theoretical agendas of its critics: " $\{b\}$ reaching the divide at the core of planning and geography will be possible only to the extent that the developers of Geographic Information Systems are willing to relinquish their positivist assumptions" (Lake, 1993, 405).

Intimations of positivism were not confined to critics of GIS. In an article titled "GIS and urban studies: positivism, post-positivism, and beyond," Daniel Sui (1994) presented a "progress report" on the use of GIS in urban planning. GIS savvy himself, Sui nevertheless accepted the premise that GIS is (or has been) positivist. Sui's was the first contribution from within GIS to engage fully with the epistemological bases of critical inquiries into GIS. Using the philosophical language and frameworks of his 
peers in social geography, Sui illustrated the extent to which recent GIS professional meetings and journals have addressed ethical issues, concluding that " $\{\mathrm{t}\}$ hese efforts speak one thing loud and clear: that is, the GIS community has realized that the implementation of GIS should go beyond mere technical decisions justified by matters of efficiency and give the ethical use of this information technology a serious consideration" (Sui, 1994, 271).

In closing, Sui $(1994,272)$ suggested a cross-pollination between GIS theory and social theory, a feat that would require "postmodernists to relinquish their playful cynicism in their critiques on the scientific chauvinism of GIS". The rationale for this requirement is that neither "meticulous" positivism or the philosophically refined "postpositivist critiques can illuminate the entire picture of urban reality" (Sui, 1994, 272). Sui's petition that no lens on reality can ever be entirely discounted remains an important entreaty for geographers.

\section{Promoters and Antagonists of Automated Geography - 1993}

In 1993, Jerome Dobson, a GIS researcher at the Oak Ridge National Laboratory, wrote an enthusiastic piece for the Professional Geographer $[(P G)]$ entitled "Automated geography". In an optimistic tone, Dobson outlined the philosophical versatility of "automated techniques" (GIS, remote sensing, computer graphics), pointing out their utility in both "nomothetic" and "idiographic" studies (Dobson, 1993, 136). His essay spawned eight responses which were published in a subsequent issue. Controversy and high feeling are the stuff of compelling reading and ten years later another editor of [the] $P G$ invited Dobson, as well as selected critics of GIS, to comment on the original essay.

Dobson was the first in line to comment on his decade-old testimonial to GIS. While acknowledging that "GIS does not address social issues, especially those that occur in a decision space somewhat independent of Euclidean space", Dobson (1993, 435) explained that emphasis in geography "reflects priorities that societies place on various issues". Lack of attention to issues relevant to cultural geographers was not a limitation of GIS but rather an indication of research priorities which typically favored emphasis on physical resources and infrastructural development. As evidence that GIS can be useful in human geography, Dobson cited the success of its use in marketing - a move clearly not intended to assuage critics' concerns about the effects of GIS.

Dobson's article was consistent with a popular strategy of articulating uses of GIS while observing that cultural geographers have remained ignorant of its applications. He noted that, by 1993, GIS was a three billion dollar industry and "to science and society at large, GIS is undoubtedly the greatest agent of change in geographic capability and awareness since the Renaissance", (Dobson, 1993, 435) despite earning little respect by cultural geographers. While this comment smacked of promotionalism, it did testify to a disparity between reception of GIS inside and 
outside of the academy. It is also indicative of a climate in which GIS researchers perceived the need to articulate and justify their research to peers.

Responses from both John Pickles (1993) and Eric Sheppard (1993) augured a more meaningful debate between factions. For the first time, critics acknowledged that GIS had legitimate application. But Sheppard (1993, 458) worried that structuralist, interpretative and feminist approaches might be discarded in favor of empirical (and categorizable) data, in effect, that "postpositivist" epistemologies would be side-lined in favor of quantifiable data. Sheppard further suggested that information systems do not necessarily produce more comprehensive analyses and that their legitimacy is frequently suspect given the prevalent use of secondary data sets. Sheppard drew attention to algorithmic manipulation, central to GIS, as a means of privileging Boolean logic and reductionist problem-solving at the expense of "historicalhermeneutic and critical-emancipatory knowledge $\{\mathrm{s}\}$ " (Habermas, cited in Sheppard, 1993, 459).

Pickles' objections were also epistemological. GIS was perceived as a means of ushering back a Cartesian methodology which was, by its very nature, a "doomed ... discourse on method" (Pickles, 1993, 451). He felt Dobson's vision of a geography enhanced by GIS ignored the "strong critiques of the reductionist ontology of spatialism" developed by human geographers in the 1980s which "challenged geographers to rethink the meaning of space, problematized the dominance of natural science method in the study of social phenomena, and raised questions about the underlying ontology of objects, location, and application on which spatial analysis was predicated" (Pickles, 1993, 452). Pickles corroborated these accomplishments on the part of cultural geographers by listing areas of geographic research for which GIS is inadequate. Cultural geographers clearly outweighed GIS practitioners in Pickles' methodological equation.

\section{The Sum of the (Initial) Difference}

By 1993, with the publication of the second forum on automated geography, sides had been taken. While initial critiques of GIS covered a range of perceived shortcomings, positivism or, more generally, epistemology had emerged as a basis for scrutinization of GIS. Human geography critics felt GIS failed to accommodate less rational, more intuitive analyses of geographical issues, and that its methodology, by definition, excluded a range of inquiry. GIS scholars, meanwhile, saw the value of their techniques being denigrated without really realizing why. As Dobson insisted, GIS practitioners recognized the value of idiographic study. The implicit question of why human geographers did not reciprocate with an acknowledgment of the power of GIS hung in the air. An either/or theme to discussions about methodology prevailed.

GIS, as an emerging technological phenomenon, was itself changing. Software prices, though still high by today's standards, were dropping as commercial ventures 
introduced competing environments. GIS had also shifted from being primarily a tool for land-use planners to what was to become geographic information science (GISci). The technology reflected a broader shift in the way geographical (and all) information "is collected, perceived, managed and used, and GIS \{was\} as good an umbrella label as any for what \{was\} happening" (Goodchild, 1991, 336). Information was increasingly available in digital format and to many advocates of GIS, it seemed inevitable that computerized spatial analysis would follow. In as much as technology is a social process, GIS was a sign of progression toward an information society.

Critics were certainly aware of this transition but they perceived its potential differently than did their counterparts in GIS. Dobson, Openshaw and Goodchild saw GIS as a tool which could extend the range of geographical analysis by incorporating larger data sets and allowing geographers to ask questions about spatial relationships that were unrestricted by the number of variables or processing power. It was a tool that extended the possibilities of research and inquiry. Pickles, by contrast, was anxious that GIS should not be used to extend a cybernetic "grid of control on the planet" (Haraway, 1991, 54). He drew closely from Donna Haraway's famous essay "A cyborg manifesto" (1991) to call attention to ways in which computer applications express social relations. Pickles, following Haraway, argued that technology is a social process and, as individuals, we have a responsibility to engage with new technologies in order to ensure they do not perpetrate unequal relations of power or other injustices. Here Pickles, with Sheppard and others, makes an important intervention on two counts: 1) by drawing attention to ways in which technology is enmeshed in social relations; and 2) by demonstrating that geographers are not excused from responsibility for ways in which GIS is developed and applied. Despite the power and validity of this argument, a gulf of language separated critics from practitioners of GIS.

Critics of GIS generally express their concerns in socio-theoretical terms, distant from the language of the technology. Nor is there evidence that many of them read GIS journals. The matrix of language, in which their critiques are necessarily situated, baffles many GIS researchers whose philosophic training ended with Karl Popper and Thomas Kuhn. GIS practitioners are not well versed in the language of social theory used to diagnose epistemological or ethical shortcomings in their field. It is fair to add that GIS researchers have refrained from using language specific to GIS and its digital representational systems when replying to critiques. Openshaw's (1992) intimation that language divides GIS and its critics to a greater extent than substantive issues may well be true but, in the early 1990s, neither side was interested in any ameliorative conclusions.

Textual jousts on the part of critics and practitioners of GIS between 1990 and 1994 laid the groundwork for continuing antagonism though, ultimately, as we shall see, a total schism was avoided. A conference designed to bring together antagonists and defenders of GIS was organized at Friday Harbor in Washington State in November 1993. It marked the beginning of increased co-operation between the two groups. 


\section{Friday Harbor: Laying it on the Table}

A surge of publications, beginning in 1995, on the epistemological, economic and discursive underpinnings of the technology represented a second wave of interrogations of GIS, many of which were both more substantive and engaged with the technology. Augured by the conference in Friday Harbor, this second set of exchanges was initiated as a response to the disciplinary friction documented in the early 1990s. Friday Harbor brought critics of GIS and its proponents to the table, ending the overt antagonism of squabbles in the first wave of GIS debates.

The meeting at Friday Harbor was organized by Tom Poiker, a long-standing GIS researcher, in a deliberate effort to reconcile factions in geography. The organizing committee included both Eric Sheppard and John Pickles, however. Wind of John Pickles' forthcoming Ground Truth (1995c) had blown through the geography community and there was increasing recognition that the purported rift in geography demanded attention. The meeting ultimately led to a proposal for [...] NCGIA (National Center for Geographic Information Analysis) Initiative 19 to study the social consequences of GIS. It also marked a shift in the tone of the debate. The group assembled at Friday Harbor brought to the table a range of perspectives about GIS, an opportunity for intradisciplinary communication which had thus far eluded debates over GIS.

The conference and the NCGIA Initiative which came out of it [were] summarized by Eric Sheppard in Environment and Planning A (1995). Sheppard's text is worthy of close attention as a barometer of critics in 1995. While it marked the beginning of closer cooperation between GIS and its dissenters, it also elucidated the terms on which critics understood the alliance to be based. Sheppard made three main points about the development of GIS. First, technological designs have far-reaching and lasting effects. In the case of GIS, inadvertent biases in the system affect "academic conceptualizations of geography" (Sheppard, 1995, 1027). Sheppard's important argument about the social and contingent nature of GIS (and all technology) summarized the concerns of many critics: "the fundamental question is whether the logic of GIS, as a result of design decisions .... privileges certain views of the world over others" (Sheppard, 1995, 1027). Sheppard's second point concerned ways that GIS privileges certain conceptualizations and world views. He reiterated that "GIS development is dominated by private sector firms rather than public agencies ... and GIS finds greater use in the corporate planning decisions of established public and private institutions" (Sheppard, 1995, 1027). Sheppard's third argument was two-fold: 1) GIS is, at present, not a democratized technology in that it is neither accessible physically or technically to those on the fringes of industry or large institutions; and 2) even if GIS were available to everyone who owned a computer, it would still not be a democratized technology as it would continue to embody algorithmic thinking, itself limited. 


\section{The Second Wave: A Chorus of (Measured) Objection to GIS}

Proceedings of the conference at Friday Harbor were published in a special issue of Cartography and GIS (CAGIS) in 1995. They were followed in the same year by Ground Truth, a collection of essays edited by John Pickles. These two volumes collectively marked a second wave of critiques of GIS. If earlier reproaches evolved as conversations between critics and proponents of GIS, the second wave was a chorus. As a result of the publication of both Ground truth and the CAGIS anthology, 20 essays in 1995 were based on epistemological and ethical flaws purported to be inherent in GIS. With few exceptions the contributors found much amiss. The antagonism expressed in earlier debates was, however, replaced by more subtle, politically savvy and substantive analyses. Issues such as epistemological integrity, gender, class, limitations of visualization, Cartesian perspectivalism and rationalism were addressed. Though many of these issues had been raised in the first wave of critiques, they were now more steeped in social theory than had previously been the case.

Originally a project envisaged by both Pickles and the late Brian Harley, Ground Truth represented a set of social critiques of GIS. It was theoretically influenced by the ground-breaking work of Harley on the relationships between maps and power. Harley claimed that maps have always been a mechanism for depicting and producing social relations. It is taken for granted, he maintained, that the king's castle should be depicted in a large size on a feudal map while whole clusters of feudal cottages are absent. The map is not the territory but a representation of social relations (Harley, 1992, 233-38). Pickles [...] extended this analysis to GIS, declaring that GIS systems and research programs are marketed with the promise of being able to enhance understanding and increase people's control over their own and others' lives (Pickles, 1995a, 6) - a process he referred to as the "colonization" of everyday life (Pickles, 1995b, 224). GIS practitioners were not, however, ignorant of the ways maps could be used in the interests of power. Mark Monmonier's book How to lie with maps (1991) tackled precisely the same issues, illustrating that maps are a means to exercise and enforce relations of power.

Critiques of GIS had, by 1995, taken Harley's analysis a step further, asserting that GIS not only represents but perpetrates certain relations of power. This view corresponded to sociologist John Law's contention that the vision of modernity orders societies, a dream sustained by the belief that they can be ordered (Law, 1994). The purported propensity of GIS to order society has historical roots. Law noted that, between 1400 and 1800, Europe witnessed the introduction of new approaches to social organization in which maps were critical for the representation and imposition of the "truth" (Law, 1994, 7). Power may be internal to maps, but critics linked it explicitly to GIS. Harley's legacy was an abiding interest in the relationship between maps and power among cultural geographers. This was consolidated with the rise of GIS and a perceived need to gain some control over its effects within the discipline of geography. 
By 1995, then, substantive issues were intertwined with responses to the specter of an ascendant GIS. A rhetorical shift was also evident. Rather than forums, these arguments were dominated by critics of GIS though, significantly, a number of GIS practitioners had joined their ranks. While positivism was still regarded as the epistemological basis of the technology, a more varied analysis of GIS was emerging. Critics covered a gamut from representation to ethics, from gender to deconstruction, from positivism to instrumental rationalism. More philosophically refined than their predecessors, many arguments introduced important social questions about GIS. The language of these critiques remained, however, that used in cultural studies and social theory - a language which did little to build alliances with GIS advocates who frequently claimed they could barely decipher critics' messages (Clarke, pers. interview, 1998; Mark, pers. interview, 1998; Phoenix, pers. interview, 1998).

Problems with positivism remained an underlying motif of the 1995 critiques. According to Peter Taylor and Ronald Johnston (1995), GIS was a collection of quantitative tools for data analysis constituting classical empiricism. The technology was regarded as having emerged from a positivist tradition with an emphasis on solving technical problems as well as improving technical interfaces (Miller, 1995). Pickles substantiated these claims in Ground Truth: "We can glimpse here the unconscious process of myth-making through which the invention of a positivist past is used to justify a progressive positivist present" (Pickles, 1995a, 19). GIS's relationship to positivism was linked by critics to the quantitative revolution (Taylor and Johnston, 1995). The possibility of a "progressive" positivist future was generally regarded skeptically. GIS was, by implication, a means of limiting the proliferation of epistemologies in geography.

Positivism, in this context, seemed very vague, given that so much research could fall under its rubric. More specific epistemological limitations of GIS were better substantiated. Computers, as Howard Veregin (1995) pointed out, do impose limitations on questions that can be asked by virtue of their architecture. Data structures also restrict what kinds of information can be coded (Curry, 1995b); ethical statements, for instance, are difficult to classify as are expressions of emotion. Critics also identified a number of ethical shortcomings of predominant applications of GIS. This line of criticism focused on under-representation of marginalized peoples (Rundstrom, 1995; Sheppard, 1995b; NCGIA, 1996); social consequences of meansdriven technology; surveillance enhancement (Curry, 1995a; Goss, 1995; Roberts and Schien, 1995); unregulated dissemination of GIS into marketing (Crampton, 1995; Goss, 1995); lack of attention to underlying social factors (Taylor and Johnson, 1995); black-boxing of algorithmic processes (Curry, 1995b; Goss, 1995); subject-object disjunction (Veregin, 1995); and the profit motive in GIS innovation (Veregin, 1995). Many of these limitations were in the realm of ethics and led, therefore, to a more empirical and better substantiated set of claims than those concerned simply with GIS's positivist roots. 
Theory was further grounded in discussions of surveillance. Considered the basis of an escalating erosion of privacy, surveillance was acknowledged as a consequence of GIS. Michael Curry (1995b) accurately noted that GIS had advanced the trend toward surveillance (state and market) by providing a spatial element, formerly lacking in many databases. The implication was that, as we are mapped in clusters representing certain tastes and proclivities, we lose the privacy needed to maintain individual freedoms (Curry, 1995b). The mapping of North American consumers was, for critics of GIS, linked to social control of the sort Pickles had warned about in 1993. Furthermore that control was envisaged as both political and economic. The means by which GIS allows states to attract investment, by identifying exploitable resources, peoples and regions, enhances the power of corporations (Pickles, 1995b; Roberts and Schein, 1995). Contributions of GIS to surveillance efforts constituted, in the eyes of its 1995 critics, a means of ensuring the continuation of asymmetries of power.

\section{Between a Rock and a Hard Place: After Friday Harbor, Before Initiative 19}

There was ostensibly little more basis for unity or co-operation among factions of geography in the mid-1990s than there had been at the beginning of the decade, but this impression was deceiving. First of all, timelines for publication distort the chronology of events. Work on Ground Truth began several years earlier, while the publications resulting from Friday Harbor were drafted in late 1993 and appeared in a special issue of Cartography and GIS in January 1995. The second wave of critiques, therefore, represents scholarship and attitudes which evolved around the same time as the angry, anti-positivist debates were being published. Interestingly, it was also during that initial wave of critiques that the seeds of later co-operation were sown. Participants at the Friday Harbor conference discussed the beginnings of what would become NCGIA Initiative 19 on "GIS and society". And Friday Harbor was convened precisely for the purpose of bridging differences between GIS critics and practitioners.

The second wave of critiques was nevertheless indicative of two solitudes in geography - islands that, due to commercial and academic success of GIS, seemed to be drifting apart. The lines between them were not drawn, however, exactly where one might expect. By the 1995 CAGIS issue and Ground Truth, participation by GIS scholars, as critics, in the critiques had substantially increased. This represented a shift from the early 1990s, when involvement of GISers was limited to spirited defenses of the technology. Detailed examinations of the technology were offered by Nancy Obermeyer, Nick Chrisman, Howard Veregin, Harlan Onsrud, Stacy Warren and others who combined a knowledge of GIS with an awareness of its limitations. Two islands were forming, but a small but significant number of GIS practitioners had joined critics from human geography on theirs. Defenses of GIS, meanwhile, declined. An exception was Stan Openshaw, who wrote a spirited review (1997) of Ground Truth in which he identified the potential for MAD or mutually assured deconstruction in this war of words. Critics had given some GIS practitioners little reason to doubt 
that " $\{\mathrm{c}\}$ ritical social theory is essentially destructive and individualistic" (Openshaw, 1997, 8). His conclusions spoke to a growing perception among mainstream GIS researchers that engagement in this debate was simply unproductive. There was a corresponding detachment of many GIS researchers from the fray.

There were reasons beyond defensiveness for this disengagement. Experience from the early 1990s had instructed GIS proponents that these critiques had only tangential bearing on their research. The journals, conferences, code and applications central to GIS research seemed to bear little relationship to accounts of the limitations of positivism. By 1996, GIS was a billion dollar per year business (GIS World, November 1997, 55). Job opportunities in North American geography reflected a surge in demand for GIS faculty while corresponding calls for cultural and economic geographers had ebbed. Recognition that "liveware" was required to develop and teach GIS was at an all-time high. Scratches at the door of this commercial and academic demand, by cultural critics, seemed increasing abstract and insignificant to many in GIS. Asked about the decline in responses from GISers, Karen Kemp (pers. interview, 1998) of the NCGIA noted that "everyone was just too busy".

Friday Harbor, while bringing together some critics and scholars of GIS, ironically marked a split within GIS between practitioners who responded to the language and content of the critics and those who thought it had very little to do with their own work. But, if GIS practitioners could not be homogenized, then neither could their critics. By the middle of the decade, differences in politics and strategy between critics were emerging (Curry, pers. comm.). A number of human geographers and GIS researchers had started to focus on means of practical intervention. A workshop on "Public participation in GIS" (PPGIS), held in Orono, Maine, in 1996, brought together a number of critics and researchers in GIS. This was followed in 1998 by a University Consortium for Geographic Information Science (UCGIS) panel that discussed PPGIS, under the rubric of GIS and society. Following the admonitions of Donna Haraway to engage with the cyborg rather than critique it from afar (1991), these critics initiated practical means to democratize the technology as well as increase public participation in its use. Others such as John Pickles, Michael Curry and longstanding GIS researcher Nick Chrisman focused on theorizing the inter-relationships between the social and technological. In both cases, critics and researchers of GIS cooperated.

While social scientists and scientists were rearranging their disciplinary alliances, GIS was changing. If in 1993 GIS was becoming accessible, it was by now ubiquitous. Desktop software was becoming widely available. Familiarity with UNIX was no longer a requirement for spatial analysis. GIS packages ran on Windows and Mac operating systems. Dissemination of the technology from geography into other disciplines, public administrations and commerce was a fait accompli. Critics were aware that GIS was non-negotiable. A combination of influences including dissemination of GIS, closer co-operation with GIS practitioners, a more nuanced 
understanding of the technology, as well as the passage of time contributed to shifts in the style and content of critiques.

\section{Back Into the (Kinder, Gentler) Ring: The Third Wave of Critiques}

In a pithy and trenchant introduction to the science wars published in The Economist (December 1997), the authors conclude their "battle map" of the dispute by suggesting a temporary exchange between factions in an effort to promote mutual understanding. The Economist predicted that such a confab might "surprise both sides" (The Economist, 1997, 79). NCGIA Initiative 19 (I19), first proposed at Friday Harbor, represented precisely such an interchange, having brought together GIS researchers and social theorists. This forum was extended by I19 specialist meetings.

Initiative 19: the social implications of how people, space, and environment are represented in GIS was sponsored by the NCGIA, itself funded by the National Science Foundation. The NCGIA was initially created to support "a center for the advancement" of GIS, but since expanded its mission to entail "advanced geographic research" (Goodchild and Mark, 1993, 219). Shifts in the goals of the NCGIA reflect recognition that GIS and geography are inseparable. The I19 steering committee was a mix of social geographers and GIS scholars. Approved in 1995, the first meeting was held in early 1996. As a consequence of promoting disciplinary space for GIS and its critics to work together on issues relating to "GIS and society", I19 marked the beginning of publications more moderately critical of GIS. These essays were far more invested in the continuation of GIS while remaining sensitive to its repercussions (Curry, 1997; Pickles, 1997, 1998). I19 created an environment which followed one condition for shared communities of interest: mutual dependence. The initiative further shifted the relationship between critics and GIS researchers as it somewhat integrated the former into the institutional body of the NCGIA. In the process, critiques of GIS were both legitimated and incorporated. Among the repercussions of this shift in critiques of GIS was recognition that 1) GIS is a permanent feature in the geography landscape; 2) the agency with which to resist the potentially destructive implications of GIS technology (military and surveillance) could be fostered; and 3) the success of critics as well as advocates of GIS depended on its continuation. The initiative itself was a formalization of the intimation, by critics of GIS, that technology is always and irrevocably a social process. Its institutional home (the NCGIA) is, however, notably aligned with scientific endeavor.

Although characterized here as a kinder, gentler stage of debate, the third wave roared in like a lion. A forum, reminiscent of pre-1995 "conversations" between GIS proponents and skeptics, appeared in the June 1997 issue of the Annals [of the Association of American Geographers]. Somewhat more staged than earlier dialogs (the key players were familiar by now), the forum featured a joint article by Dawn Wright, Michael Goodchild and James Proctor (1997) who attempted to "demystify" the "persistent ambiguity" of GIS's relationship to geography and science. A response 
by John Pickles left no illusion that despite its ubiquity, GIS remains a contentious technology.

Wright et al. (1997) distinguished three main uses of GIS based on information garnered from the very popular GIS-L listserve. They determined that for a wide swath of users, GIS is a piece of software, comparable to a statistics package: useful for clarifying an issue or analyzing data. A second, more rarefied group is involved in the development and refinement of GIS software and theory. A third, sizable contingent, including many from outside geography, views GIS as a form of geographical science. Designation of GIS as a subset of the discipline was refuted by the authors, who suggested that geographic information science (GISci) has the capacity, drawing on geographic primitives, to "describe, analyze, model, reason about, and make decisions on phenomena distributed on the surface of the earth" [...] and, more fundamentally, analyze "issues raised by the use of GIS" (Wright et al., 1997, 357-8). Wright et al. warned, however, that GISci should not be confused with current implementations of GIS, as that would bestow an authority on the science unwarranted by its current level of development.

By carving a place in the "sciences" for GISci, the authors were careful to craft a corresponding definition of science as an entity which is open and eludes conflation with positivism (perhaps a science a little like the one envisaged by critics). In such a science, GIS, with its emphasis on "visual expression, collaboration, exploration, intuition and the uniqueness of place over more traditional concerns for mathematical rigor, hypotheses testing, and generality", fits well (Wright et al., 1997, 358-9). Through this flexible vision of GISci, Wright et al. acknowledged many of the "cultural" constituents of traditional science. Its definition also incorporated components of the critics' program. Certainly the authors' revised understanding of science indicated GIS was not isolated from the discourse of social theory. At the same time, defining GISci separately from geography was an effort to establish its unique place under the umbrella of geography.

Given efforts by Wright et al. to accommodate and respond to critiques of GIS, Pickles' reply (1997) was, on the surface, disconcerting. He started [...] by emphasizing the importance of continuing discussions about the "poverty and politics of GIS theory" and observed that " $\{\mathrm{i}\} \mathrm{t}$ is even more remarkable to some of us that up to this point, there has been no thoroughgoing discussion by GIS practitioners and theorists about the epistemology of their subject, the ontology of their objects, and the political commitments embedded in their practices" (Pickles, 1997, 363-64). Pickles speculated that this reluctance to engage at an epistemological level was caused by "a genuine confusion" about social theory (Pickles, 1997, 369). Pickles described GISers, including Wright et al., as still writing in a theory-free mode which left him with "a sense of déjà $v u$, of old ground being replowed, and of complex issues being mapped onto pre-existing theoretical frameworks" (Pickles, 1997, 369). Pickles seemed reluctant to abandon his reading of GIS as "rooted in hypothetico-deductive models" (Pickles, 1997, 363) and described Wright et al. as "talk\{ing $\}$ back and forth between 
positivist defense and post-positivist reworking $\{\mathrm{s}\}$ of GIS assumptions and epistemology" (Pickles, 1997, 364). The reader is left with a sense that the GIS scholars were well intentioned if still a little epistemologically naive.

Pickles extended the promise, however, that "through the hard work of theory ... GIS might well yet find a home that sustains \{its\} intellectual pursuits and professional goals" (Pickles, 1997, 370). Pickles' gestures toward possibilities of transformation for GIS mark an implicit recognition of the contingency of both power and representation. So, despite the patronizing suggestion that GIS researchers be guided by social theorists, Pickles did open a space for a more palatable and effective genre of socio-theoretical intervention.

This aperture was sustained by Michael Curry (1997) in a more deliberate and congenial manner. In an article on the links between surveillance, privacy, vision and GIS, he explored historical and contextual meanings of privacy. Though the undisputed observation that "the ease of computer mapping, combined with the increasing availability of data sets, has made maps more readily available and made the possibility of privacy infringement much more likely" was made, Curry (1997, 692) took it in a new and refreshing direction. His set of observations on the interdigitization of law, technology and culture disrupted a pattern of laying the onus of responsibility on technology. Instead he sought to unravel the complexity and contradictions inherent in digital representation and, more to the point, ways in which digital individuals can reinvent themselves to accommodate the sure knowledge they are incompletely inscribed in a database.

By showing that what is considered public or private is negotiated in the discourse of jurisprudence and politics, Curry shifted the onus of responsibility from GIS to its social context, explicitly invoking possibilities for resistance in every system, digital or analog. By concluding that "it makes more sense to see us as authors of our own lives, of our identities as real and virtual" (Curry, 1997, 695), Curry acknowledged the culpability and, conversely, the power of individuals to adjust to social conditions. The onus was shifted from GIS to a complex matrix of juridical, cultural, political and scientific realms from which it is produced and in which it operates. His tactic indirectly buttressed Openshaw's (1997) antipathy for social criticism of GIS which leads to "mutually assured deconstruction" and promotes a disciplinary climate supportive of both technical and qualitative research.

The third wave of GIS critiques represented a more nuanced analysis of power. In this present period of negotiation between GIS and geography, critics have illustrated means by which possible oppressions supported by GIS technology can be resisted at an individual and social level - ways in which power is flexible and circuitous (Curry, 1997). By 1998, both critics and defenders of GIS were better informed about the agendas and implications of each other's work. A willingness to integrate dialog and debate over the effects of GIS as well as its epistemological bases was well established and supported by institutional structures. In 1992, Pickles notably solicited an entry from GIS scholars Michael Goodchild and Howard Veregin for 
Ground Truth. Such exchanges are now routine. The newest edition of Geographical Information Systems, fondly referred to as the "big book" in GIS circles, includes entries from GIS critics (Curry, 1999b; Pickles, 1999) This mutual support reflects the integration of critical analyses of GIS through NCGIA I19, and the ongoing Varenius project, as well as invitations to contribute to mainstream GIS texts and meetings which had a similar effect. The science wars in geography are currently marked by their emphasis on negotiation (Pickles, 1999).

\section{Toward a Conclusion: Fixing the Factionalization in Geography}

Critics have had considerable impact on GIS and the discipline as a whole. Some of their suggestions about the epistemological implications of GIS as well as the relationship between society and technology have been incorporated by GIS scholars (Poiker, pers. interview, 1997; Chrisman, pers. interview, 1998). A scattering of GIS practitioners have joined their peers in human geography in examining the social dimensions of GIS (Harvey, 1997). A number of PPGIS projects are springing up throughout North America (Craig, 1998; Obermeyer, 1998). Though initial debates were marked by hostility, later critiques have evolved into more co-operative ventures between social scientists and scientists within geography. There is evidence of a genuine desire on the part of many critics and GIS practitioners to ensure responsible GIS at both the application and algorithmic level.

Despite an increased congeniality between the two solitudes of geography, however, the more substantive issue of the effects of these debates in geography has not been examined. Nor has the efficacy and legitimacy of the critical approaches, used by critics to interrogate GIS, been addressed. GIS has been somewhat homogenized, regarded as a single entity rather than a loosely defined set of practices. GIS consists of combinations of software and hardware but it is also an expression of multiple discourses. Linked at the machine and code level to computer science and, at a representational level with mathematics, GIS inhabits a world of numerical and representational strategies. GIS is not an end product of the Enlightenment and scientific rationality. Rather, a myriad of practices sustains the technology; GIS incorporates intuitive, cognitive, visual and textual elements in its use and structure. Early critiques of GIS, especially, were inattentive to the complexity of the technology and the science, focusing instead on cartographic representations. The result has been a sense among a number of GIS scholars that the technology has been found to be inadequate, undermining the intellectual value of their work (Buttenfield, pers. interview, 1998; Estes, pers. interview, 1998; Marble, pers. interview, 1998). Moreover, emphasis on epistemology has drawn attention away from the architecture of the technology where many shortcomings are ultimately located.

At the beginning of the new century, two distinct genres of critique have emerged. The first involves a small number of critics from GIS as well as human geographers who are critically engaged with GIS in a practical, applied fashion. Their 
efforts have been focused on issues such as the effects of digital surveillance, the ontological implications of interoperability and the means of democratizing GIS (Curry, 1999a; Egenhofer, 1999; Sieber, 1999). These discussions have been conducted largely in the language of GIS and have, accordingly, been better integrated into GIS research (Barndt, 1998; Egenhofer, pers. interview, 1999; NCGIA, 1999). The second genre might be called "meta-GIS". It incorporates social theory and increasingly discourse and ideas from STS, while bearing little perceptible application to practicing GIS researchers. The esoteric nature of this writing limits its application in a computational environment. Its contribution lies, rather, in situating GIS within a larger body of writing about science and technology, intended for a cultural studies audience.

There has been a tendency, moreover, to prescribe social theory rather than algorithmic revision for what ails GIS. Pickles $(1997,370)$ stated that "any emergent science of geographic information must now wend its way into and through longstanding debates and theoretical frameworks of great complexity". His suggestion for reviewing the theoretical evolution of cultural geographers over the past 25 years presupposes that any individual or discipline exposed to the same arguments as he would come to the same conclusions about GIS. That supposition follows an argument first developed by Max Weber (Bendix, 1962) and more recently outlined by Edward Said $(1996,77)$ in his sketch of "expert discourses": "To be an expert you have to be certified by the proper authorities; they instruct you in speaking the right language, citing the right authorities, holding down the right territory. This is especially true when sensitive and/or profitable areas of knowledge are at stake." Said's recondite recognition that formulae for thinking are imposed when disciplinary power is at stake has purchase in the debates over GIS in geography. There has been a sense among GIS practitioners that only arguments framed in a particular discourse will be recognized by social theorists (Chrisman, pers. interview, 1998; Marble, pers. interview, 1998). Critics of GIS have, nevertheless, had considerable influence on the discipline. Their greatest effect has been to alert GIS scholars to the social ramifications of the technology as well as ways in which culture is written into the technical.

Samuel Johnson famously wrote that "a critic is a legless man who teaches running". This aphorism need not apply to critics of GIS. But if social theorists want to influence GIS, then they must make their arguments relevant to the technology (Demeritt, 1996). In order to take the next step, to influence GIS at the machine level, critics must learn to communicate in the vocabulary of the technology. This requires a familiarity with the computational and theoretical bases that underlie GIS. An understanding of the parameters of formalization that govern semantics and operations in GIS would allow critics to exert considerably more influence. A critic who can pinpoint ways in which a classification system curtails use of critical information (Gray, 1997) or how a given algorithm might better express spatial relationships is likely to gain the ear of GIS researchers. Current research on ontologies and interoperability demonstrates the viability of incorporating social, philosophical and technical considerations in GIS (Kuhn, 1994; Couclelis, 1996; Frank and Raubal, 
1998; Smith and Mark, 1998). This is the tactic suggested by Donna Haraway (1991) when she urged that social theorists engage in the construction of the cyborg rather than critique it from afar. This is not to imply that criteria for criticism of GIS include double PhDs. Rather, that constructive critique requires a depth of understanding about the science or technology being investigated (Kitcher, 1998).

\section{References}

Barndt, M. 1998. GPS public participation GIS - barriers to implementation. Cartography and Geographic Information Systems 25, 105-12.

Barnes, T. 1993. Whatever happened to the philosophy of science? Environment and Planning A 25, 301-4.

Bendix, R. 1962. Max Weber: An Intellectual Portrait. Garden City, NY: Anchor Books.

Billinge, M., D. Gregory and R. Martin (eds.). 1984. Recollections of a Revolution: Geography as Spatial Science. London: Macmillan.

Couclelis, H. 1996. Towards an operational typology of geographic entities with illdefined boundaries. In, P.A. Burrough \& A. U. Frank (eds.), Geographic Objects with Indeterminate Boundaries. London: Taylor \& Francis, pp. 45-55.

Craig, W. J. 1998. How and why community groups use maps and geographical information systems. Cartography and Geographic Information Systems 25, 95104.

Crampton, J. 1995. The ethics of GIS. Cartography and Geographic Information Systems 22, 84-89.

Curry, M. 1999a. Technological regimes and the evolution of the private. Presented at the Intersections: Society, Technology, and Geographic Thought workshop on GIS, Rough River Resort, KY 29 April-2 May.

Curry, M. 1999b. Rethinking privacy in a geocoded world. In, P. A. Longley, M. F. Goodchild, D. J.Maguire \& D. W. Rhind (eds.), Geographical Information Systems: Principles, Techniques, Management and Applications. New York: Wiley, pp. 757-66.

Curry, M. 1997. The digital individual and the private realm. Annals of the Association of American Geographer 87, 681-99. 
Curry, M. 1995a. Rethinking rights and responsibilities in geographic information systems: Beyond the power of the image. Cartography and Geographic Information Systems 22, 58-69.

Curry, M. 1995b: GIS and the inevitability of ethical inconsistency. In, J. Pickles (ed.), Ground Truth. New York: Guilford Press, pp. 68-87.

Demeritt, D. 1996. Social theory and the reconstruction of science and geography. Transactions, Institute of British Geographers 21, 484-503.

Dobson, J. 1993. Automated geography. Professional Geographer 35, 135-43.

Economist, The. 1997. You can't follow the science wars without a battle map. 13 December, 77-79.

Egenhofer, M. 1999. The emperor's new clothes. Presented at the annual meeting of the Association of American Geographers, Honolulu, HI, 27 March.

Fish, S. 1996. Professor Sokal's bad joke. The New York Times 21 May, A23.

Frank, A. U. and M. Raubal. 1998. Specifications for interoperability: formalizing image schemata for geographic space. In, T. K. Poiker \& N. Chrisman (eds.), Proceeding from the 8th International Symposium on Spatial Data Handling, Vancouver, BC: IGU, pp. 331-48.

Goodchild, M. F. and D. M. Mark. 1993. GIS, geography and the NCGIA. Professional Geographer 45, 216-19.

Goodchild, M. F. 1991. "Just the facts". Political Geography Quarterly 10, 335-37.

Goss, J. 1995: Marketing the new marketing: The strategic discourse of geodemographic information systems. In, J. Pickles (ed.), Ground Truth, New York: Guilford Press, pp.130-70.

Gray, M. V. 1997. Classification as an impediment to the reliable and valid use of spatial information: A disaggregate approach. In, S.C. Hirtle \& A.U.Frank (eds.), Spatial Information Theory: A Theoretical Basis for GIS. COSIT '97, Berlin: Springer, pp. 137-49.

Gross, A. G. 1996. The Rhetoric of Science. Boston, MA: Harvard University Press.

Gross, P. and N. Levitt. 1994. Higher Superstition: The Academic Left and Its Quarrel with Science. Baltimore, MD, and London: Johns Hopkins University Press.

Gross, P. R., N. Levitt, N. and M. W. Lewis. 1996. The Flight from Science and Reason. New York: The New York Academy of Sciences. 
Haraway, D. 1991. Simians, Cyborgs and Women: The Reinvention of Nature. New York: Routledge.

Harding, S. 1991: Whose Science? Whose Knowledge? Thinking from Women's Lives. Ithaca, NY: Cornell University Press.

Harley, B. 1992. Deconstructing the map. In, T.J. Barnes \& J.S. Duncan (eds.), Writing Worlds: Discourse, Text and Metaphor in the Representation of Landscape. New York and London: Routledge, pp. 231-47.

Harvey, F. 1999. B-ANT-O: Boundary A-NT objects: Trails and trail markers. Paper presented at the Intersections: Society, Technology, and Geographic Thought workshop on GIS, Rough River Resort, KY, 29 April-2 May.

Harvey, F. 1997. From geographic holism to geographic information systems. Professional Geographer 49, 77-85.

Harvey, F. and Chrisman, N. R. 1998: Boundary objects and the social construction of GIS technology. Environment and Planning A 30, 1683-94.

Kitcher, P. 1998. A plea for science studies. In N. Koertge (ed.), A House Built on Sand: Exposing Postmodernist Myths about Science, New York: Oxford University Press, pp. 32-52.

Koertge, N. (ed.). 1998. House Built on Sand: Exposing Postmodernist Myths about Science, New York: Oxford University Press.

Kuhn, W. 1994. Defining semantics for spatial data transfers. In, T.C. Waugh \& R.G. Healey (eds.), Advances in GIS Research: Proceedings of the Sixth International Symposium on Spatial Data Handling, London: Taylor \& Francis, pp. 973-87.

Lake, R.W. 1993. Planning and applied geography: Positivism, ethics, and geographic information systems. Progress in Human Geography 17, 404-13.

Latour, B. 1988. The Pasteurization of France. Cambridge, MA: Harvard University Press.

Latour, B. 1987. Science in Action. Cambridge MA: Harvard University Press.

Law, J. 1994. Organizing Modernity. Oxford: Blackwell.

Miller, R. P. 1995. Beyond method, beyond ethics: Integrating social theory into GIS and GIS into social theory. Cartography and Geographic Information Systems 22, 98-103.

Monmonier, M. 1991. How to Lie with Maps. Chicago, IL: University of Chicago Press. 
NCGIA 1999. The Ontology of Fields: Report of a Specialist Meeting Held under the Auspices of the Varenius Project. Technical Report 99-7. Santa Barbara, CA: University of California.

NCGIA 1996. GIS and Society: The Social Implications of How People, Space and Environment Are Represented in GIS. Technical Report 96-7. November. Santa Barbara, CA: University of California.

Obermeyer, N. 1998. The evolution of public participation GIS. Cartography and Geographic Information Systems 25, 65-66.

Openshaw, S. 1991. A view on the GIS crisis in geography, or, using GIS to put Humpty-Dumpty back together again. Environment and Planning A 23, 621-28.

Openshaw, S. 1992. Further thoughts on geography and GIS: A reply. Environment and Planning A 24, 463-66.

Openshaw, S. 1997. The Truth about Ground Truth. Transactions in GIS 2, 7-24.

Pickering, A. 1995. The Mangle of Practice: Time, Agency, and Science. Chicago, IL, and London: University of Chicago Press.

Pickles, J. 1999. Arguments, debates and dialogues: The GIS social theory debate and the concern for alternatives. In, P.A. Longley, M. F. Goodchild, D. J. Maguire \& D. W. Rhind (eds.), Geographical Information Systems: Principles, Techniques, Management and Applications. New York: Wiley, pp. 49-60.

Pickles, J. 1997. Tool or science? GIS, technoscience and the theoretical turn. Annals of the Association of American Geographers 87, 363-72.

Pickles, J. 1995a. Representations in an electronic age: Geography, GIS, and democracy. In, J. Pickles (ed.), Ground Truth. New York: Guilford Press, pp. 130 .

Pickles, J. 1995b. Conclusion: towards an economy of electronic representation and the virtual sign. In, J. Pickles (ed.), Ground Truth. New York: Guilford Press, pp. 223-40.

Pickles, J. (ed.). 1995c. Ground Truth. New York: Guilford Press.

Pickles, J. 1993. Discourse on method and the history of discipline: Reflections on Jerome Dobson's 1993 “Automated geography”. Professional Geographer 45, 451-55.

Roberts, S. M. and R. H. Schein. 1995. Earth shattering: Global imagery and GIS. In, J. Pickles (ed.), Ground Truth. New York: Guilford Press, pp. 171-95. 
Rorty, R. 1989. Contingency, Irony and Solidarity. New York: Cambridge University Press.

Rouse, J. 1996. Engaging Science: How to Understand Its Practices Philosophically. Ithaca, NY, and London: Cornell University Press.

Rundstrom, R. 1995. GIS, indigenous peoples, and epistemological diversity. Cartography and Geographic Information Systems 22, 45-57.

Said, E. W. 1996. Representations of the Intellectual. New York: Vintage Books.

Sheppard, E. 1993. Automated geography: What kind of geography for what kind of society? Professional Geographer 45, 457-60.

Sheppard, E. 1995. Sleeping with the enemy, or keeping the conversation going? Environment and Planning A 27, 1026-28.

Sieber, R. 1999. Conforming (to) the opposition: A research agenda for geographic information systems in the conservation movement. Paper presented at the Intersections: Society, Technology, and Geographic Thought workshop on GIS, Rough River Resort, KY, 29 April-2 May.

Smith, N. 1992. History and philosophy of geography: Real wars, theory wars. Progress in Human Geography 16, 257-71.

Smith, B. and Mark, D. M. 1998: Ontology and geographic kinds. In, T. K. Poiker \& N. Chrisman (eds.), Proceeding from the $8^{\text {th }}$ International Symposium on Spatial Data Handling. Vancouver, BC: IGU, pp. 308-20.

Sokal, A. 1996a. Transgressing the boundaries: Toward a transformative hermeneutics of quantum gravity. Social Text 46/47, 217-52.

Sokal, A. 1996b. Aphysicist experiments with cultural studies. Lingua Franca 6, 6264.

Sui, D. Z. 1994. GIS and urban studies: Positivism, post-positivism, and beyond. Urban Geography 15, 258-78.

Taylor, P. J. 1990. GKS. Political Geography Quarterly 9, 211-12

Taylor, P. J. and R. Johnston. 1995. GIS and geography. In, J. Pickles (ed.), Ground Truth. New York: Guilford Press, pp. 68-87.

Taylor, P. J. and M. Overton. 1991: Further thoughts on geography and GIS. Environment and Planning A 23, 1087-90. 
Veregin, H. 1995. Computer innovation and adoption in geography: A critique of conventional technological models. In, J. Pickles (ed.), Ground Truth. New York: Guilford Press, pp. 88-112.

Walton, J. 1995. How real(ist) can you get? Professional Geographer 47, 61-65.

Wright, D. J., M. F. Goodchild and J. Proctor. 1997. Demystifying the persistent ambiguity of GIS as "tool" versus "science." Annals of the Association of American Geographers 87, 346-62. 